\title{
Germination and inactivation of Bacillus coagulans and Alicyclobacillus acidoterrestris spores by high hydrostatic pressure treatment in buffer and tomato sauce
}

\author{
Anne Vercammen, Bram Vivijs, Ine Lurquin, Chris W. Michiels*

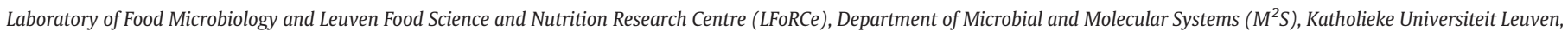
Kasteelpark Arenberg 22, B-3001 Leuven, Belgium

\section{A R T I C L E I N F O}

\section{Article history:}

Received 29 November 2010

Received in revised form 12 January 2011

Accepted 16 February 2011

Available online $\mathrm{xxxx}$

\section{Keywords:}

High hydrostatic pressure

Thermoacidophiles

Bacterial spores

Germination

Inactivation

Tomato sauce

\begin{abstract}
A B S T R A C T
Acidothermophilic bacteria like Alicyclobacillus acidoterrestris and Bacillus coagulans can cause spoilage of heat-processed acidic foods because they form spores with very high heat resistance and can grow at low $\mathrm{pH}$. The objective of this work was to study the germination and inactivation of $A$. acidoterrestris and B. coagulans spores by high hydrostatic pressure (HP) treatment at temperatures up to $60{ }^{\circ} \mathrm{C}$ and both at low and neutral $\mathrm{pH}$. In a first experiment, spores suspended in buffers at $\mathrm{pH}$ 4.0, 5.0 and 7.0 were processed for $10 \mathrm{~min}$ at different pressures (100-800 MPa) at $40{ }^{\circ} \mathrm{C}$. None of these treatments caused any significant inactivation, except perhaps at $800 \mathrm{MPa}$ in $\mathrm{pH} 4.0$ buffer where close to $1 \log$ inactivation of $B$. coagulans was observed. Spore germination up to about $2 \log$ was observed for both bacteria but occurred mainly in a low pressure window (100-300 MPa) for A. acidoterrestris and only in a high pressure window (600-800 MPa) for B. coagulans. In addition, low pH suppressed germination in A. acidoterrestris, but stimulated it in B. coagulans. In a second series of experiments, spores were treated in tomato sauce of pH 4.2 and 5.0 at $100-800 \mathrm{MPa}$ at 25,40 and $60{ }^{\circ} \mathrm{C}$ for $10 \mathrm{~min}$. At $40{ }^{\circ} \mathrm{C}$, results for $B$. coagulans were similar as in buffer. For A. acidoterrestris, germination levels in tomato sauce were generally higher than in buffer, and showed little difference at low and high pressure. Remarkably, the $\mathrm{pH}$ dependence of A. acidoterrestris spore germination was reversed in tomato sauce, with more germination at the lowest $\mathrm{pH}$. Furthermore, HP treatments in the pH 4.2 sauce caused between 1 and $1.5 \log$ inactivation of $A$. acidoterrestris. Germination of spores in the high pressure window was strongly temperature dependent, whereas germination of $A$. acidoterrestris in the low pressure window showed little temperature dependence. When HP treatment was conducted at $60{ }^{\circ} \mathrm{C}$, most of the germinated spores were also inactivated. For the $\mathrm{pH} 4.2$ tomato sauce, this resulted in up to 3.5 and $2.0 \mathrm{log}$ inactivation for $A$. acidoterrestris and $B$. coagulans respectively. We conclude that HP treatment can induce germination and inactivation of spores from thermoacidophilic bacteria in acidic foods, and may thus be useful to reduce spoilage of such foods caused by these bacteria.
\end{abstract}

(C) 2011 Elsevier B.V. All rights reserved.

\section{Introduction}

Food pasteurization by HP has become a mature technology in recent years, and the number of HP treated foods on the market is rapidly increasing worldwide. Because it is a cold process, HP does not cause heat-related deterioration phenomena like loss of vitamins and nutrients, discoloration and textural and organoleptic changes, and HP treated foods are therefore often of superior quality. In general, vegetative bacteria (as well as yeasts and molds) can be efficiently inactivated at pressures in the range of 400-600 MPa without heating, although there is still an issue with pressure-resistant strains that may survive this treatment (Benito et al., 1999; Hauben et al., 1997). Bacterial spores, on the other hand, are more resistant to HP as is the case for other inimical treatments, and have been reported to

\footnotetext{
* Corresponding author at: Laboratory of Food Microbiology, Kasteelpark Arenberg 22, B-3001 Leuven, Belgium. Tel.: + 3216 321578; fax: + 3216321960.

E-mail address: Chris.michiels@biw.kuleuven.be (C.W. Michiels).
}

withstand pressures of at least $1000 \mathrm{MPa}$, which is $400 \mathrm{MPa}$ higher than the maximum pressure currently achievable in commercial food processing (Smelt, 2002). However, HP treatment can induce germination of spores (Clouston and Wills, 1969; Gould and Sale, 1970; Nakayama et al., 1996; Sale et al., 1970; Smelt, 2002). Once germinated, the spores lose their characteristic resistance and can be inactivated by a second treatment such as pressure or heat, and HP pasteurization approaches making use of this behavior have been proposed. For example, a 6-D reduction of $B$. cereus spores could be achieved in milk, either by a single treatment at $500 \mathrm{MPa} / 60{ }^{\circ} \mathrm{C}$ for $30 \mathrm{~min}$, or by a sequential treatment for $30 \mathrm{~min}$ at $200 \mathrm{MPa} / 45^{\circ} \mathrm{C}$ to induce spore germination, followed by mild heat treatment at $60{ }^{\circ} \mathrm{C}$ for $10 \mathrm{~min}$ to kill the germinated spores (Van Opstal et al., 2004). A fundamental limitation to this approach is that HP-induced spore germination is only moderate or even completely absent at or below room temperature (Nakayama et al., 1996; Sale et al., 1970).

Although growth of most sporeforming bacteria is inhibited by low $\mathrm{pH}$, there are some notable exceptions such as Clostridium butyricum, 
B. coagulans and A. acidoterrestris, which can cause spoilage of thermally processed acidic foods (Silva and Gibbs, 2004). In the current study, we will focus on the latter two, which are considered as thermoacidophiles. $B$. coagulans has an optimum and maximum growth temperature of respectively $33-45^{\circ} \mathrm{C}$ and $55-60{ }^{\circ} \mathrm{C}$. Its spores are able to germinate and grow at pH-values as low as 4.0 , and as such it is frequently isolated from spoiled canned acidic or acidified vegetables, in particular tomato products (Evancho and Walls, 2001; Mallidis et al., 1990). A. acidoterrestris is an obligate acidophile, which grows optimally at $\mathrm{pH} 3.5$ to 4.0 and has a minimum and maximum $\mathrm{pH}$ for growth of 2.5 and approximately 5.5. A. acidoterrestris spores are generally more heat resistant than those of other acidophilic sporeformers, and cause spoilage of processed fruit and vegetables juices (Evancho and Walls, 2001; Silva and Gibbs, 2004; Splittstoesser et al., 1994). In addition, A. acidoterrestris is able to grow over a temperature range of 25 to $60{ }^{\circ} \mathrm{C}$ (Yamazaki et al., 1996).

Only few studies have addressed spore germination and inactivation of B. coagulans and A. acidoterrestris by HP. Sale et al. (1970) studied the effect of HP up to $800 \mathrm{MPa}$ on the inactivation of spores from different Bacillus and Clostridium spp. including B. coagulans in buffer. In general inactivation proceeded more rapidly at high than at low temperatures (range $25-75^{\circ} \mathrm{C}$ ) and at moderate as opposed to extreme pH-values (range $\mathrm{pH} 3.0$ - 11.5). In a separate study, the same research group reported that HP mediated germination of some bacterial spores including $B$. coagulans, shows a temperature optimum at $50-70{ }^{\circ} \mathrm{C}$ depending on the organism and the conditions, and a pH optimum around neutrality (Gould and Sale, 1970). However, only pressures up to $100 \mathrm{MPa}$ were used in this study. HP up to $600 \mathrm{MPa}$ which are more relevant to food processing also induce spore germination, but at least in $B$. subtilis the process of germination seems to be aborted at an early stage, resulting in partially germinated spores which retain resistance to some stresses (Wuytack et al., 1998). Remarkably, more recent HP studies with B. coagulans only report spore inactivation, and have not specifically addressed germination. Roberts and Hoover (1996) studied the effect of HP ( $400 \mathrm{MPa} ; 25,45$ and $75^{\circ} \mathrm{C} ; 15$ and $30 \mathrm{~min}$ ) on spores of $B$. coagulans in Mcllvaine citrate buffer ( $\mathrm{pH}$ 4.0-7.0) and observed the highest sensitivity at low $\mathrm{pH}$ and high process temperatures. In another study, the effect of HP ( $100 \mathrm{MPa}, 65-85^{\circ} \mathrm{C}, 3-12 \mathrm{~h}$ ) on the inactivation of B. coagulans spores in ketchup ( $\mathrm{pH} 4.0$ ) and neutralized ketchup $(\mathrm{pH} 7.0)$ and in potage ( $\mathrm{pH} 7.0)$ and acidified potage ( $\mathrm{pH} 4.0)$ was studied (Islam et al., 2006). B. coagulans spores tended to be more resistant in neutralized foods than in acid foods during heat and HP treatment and to be more resistant in ketchup than in potage during HP treatment. Finally, Wang et al. (2009) found that B. coagulans spores were much more resistant to $\mathrm{HP}$ (400-600 MPa) at moderately elevated temperature $\left(70\right.$ and $80^{\circ} \mathrm{C}$ ) in ultra-high temperature treated (UHT) milk than in phosphate buffer ( $100 \mathrm{mM}$, pH 6.7).

The few published HP studies with A. acidoterrestris also only document spore inactivation, not germination. Lee et al. (2002) reported that spore reduction by $\mathrm{HP}(207,414$ or $621 \mathrm{MPa}, 10 \mathrm{~min})$ was strongly temperature dependent. While viability was not appreciably reduced at room temperature, increasing levels and rates of inactivation were observed at 45,71 and $90{ }^{\circ} \mathrm{C}$ respectively. In a follow-up study, inactivation of $A$. acidoterrestris spores by HP was shown to be suppressed by high solute concentration in apple juice concentrates (Lee et al., 2006).

It can be concluded that data about the effect of HP on the spores of thermoacidophilic bacteria are fragmentary. In particular, little is known about the HP-induced germination of these spores at low $\mathrm{pH}$ under different process conditions and in real foods. This is a relevant issue because HP inactivation of spores at moderate temperature is dependent on prior germination, and spore germination of neutrophilic B. subtilis is completely inhibited at low pH (Wuytack and Michiels, 2001). Therefore, the objective of this work was to investigate the effect of $\mathrm{HP}(100-800 \mathrm{MPa})$ at different temperatures $\left(25-60{ }^{\circ} \mathrm{C}\right)$ on the inactivation and the germination of $B$. coagulans and $A$. acidoterrestris spores at low $\mathrm{pH}$ in buffer and tomato sauce.

\section{Materials and methods}

\subsection{Preparation of tomato sauce}

Tomato sauce was manually prepared by mixing the different ingredients (Table 1 ) in a sterile beaker, heating in a water bath at $70{ }^{\circ} \mathrm{C}$ without agitation to a center temperature of $65^{\circ} \mathrm{C}$, and then stirring for 10 minutes. When necessary, the $\mathrm{pH}$ was adjusted to 5.0 with $3.0 \mathrm{M} \mathrm{NaOH}$ after cooling.

\subsection{Bacterial strains and spore production}

B. coagulans LMG6326 and A. acidoterrestris LMG16906 were obtained from the LMG culture collection (Ghent, Belgium) and grown respectively on Nutrient Agar (NA) composed of Nutrient Broth No.2 (25 g/l NB; Oxoid, Basingstoke, U.K.) and Agar No.1 (12 g/l; Lab M, Lancashire, U.K.) at $37^{\circ} \mathrm{C}$ or Bacillus acidoterrestris Thermophilic Agar (BAT; Merck, Darmstadt, Germany) at $43^{\circ} \mathrm{C}$. To induce sporulation, a single colony of $B$. coagulans or A. acidoterrestris was grown in $4 \mathrm{ml} \mathrm{NB}$ or BAT broth at respectively 37 or $43^{\circ} \mathrm{C}$ with shaking $(200 \mathrm{rpm})$. After $48 \mathrm{~h}, 100 \mu \mathrm{l}$ of this suspension was transferred into $900 \mu \mathrm{l}$ sterile distilled water and surface-plated on respectively NA with $0.1 \mathrm{mM} \mathrm{MnSO}_{4}$ or Potato Dextrose Agar (PDA; Oxoid, Basingstoke, U.K.). After 10 days of incubation at respectively 37 or $43^{\circ} \mathrm{C}$, spores were harvested by rubbing the surface of the plates with a sterile swab and $5 \mathrm{ml}$ sterile distilled water. The spores were washed three times and stored in sterile distilled water at a concentration of respectively $10^{6}$ and $10^{7}$ spores $/ \mathrm{ml}$ at $-20^{\circ} \mathrm{C}$ until use. Plating of these spore suspensions before and after a heat treatment $\left(70{ }^{\circ} \mathrm{C} / 30 \mathrm{~min}\right.$ for B. coagulans (Sale et al., 1970) and $80^{\circ} \mathrm{C} /$ 10 min for A. acidoterrestris (Sinigaglia et al., 2003)) indicated that they contained less than $20 \%$ vegetative cells. For the HP experiments, non-heat treated spore suspensions were used to avoid any changes in pressure resistance. Just before the experiments, spores were suspended either in citric acid buffer $(20 \mathrm{mM}, \mathrm{pH} 4.0$ or 5.0 ), potassium phosphate buffer $(10 \mathrm{mM}, \mathrm{pH} 7.0)$ or tomato sauce $(\mathrm{pH}$ 4.2 or 5.0 ) at approximately $10^{5}-10^{6}$ spores $/ \mathrm{ml}$.

\subsection{High hydrostatic pressure treatment}

HP treatments were carried out in an eight $8 \mathrm{ml}$ vessel HP equipment (HPIU-10000, 95/1994, Resato, Roden, the Netherlands). The temperature of the vessels was controlled by a water circuit connected to a cryostat. A mixture of glycols (TR15, Van Meeuwen, Weesp, the Netherlands) was used as pressure transferring liquid. Six to eight hundred $\mu \mathrm{L}$ of the spore suspensions were sealed in sterile polyethylene bags and treated at 100 to $800 \mathrm{MPa}$ and 25 to $60{ }^{\circ} \mathrm{C}$ (initial temperature) during 10 minutes. Pressure was built up slowly (approximately $100 \mathrm{MPa} / \mathrm{min}$ ) to minimize adiabatic heating and decompression was immediate. Under these conditions, a temperature increase of approximately $5-8{ }^{\circ} \mathrm{C}$ occurs in the pressure-

Table 1

Ingredients of tomato sauce.

\begin{tabular}{lc}
\hline Ingredient & $\%(\mathrm{w} / \mathrm{w})$ \\
\hline Double concentrated tomato puree (Elvea, Antwerp, Belgium) & 25 \\
Tomato passata (Elvea, Antwerp, Belgium) & 14 \\
Sodium chloride (Fisher Scientific, Leichestershire, U.K.) & 1 \\
Modified corn starch & 3.2 \\
(Resistamyl 342, Tate and Lyle, Koog aan de Zaan, The Netherlands) & \\
Distilled water & 56.8 \\
\hline
\end{tabular}


transmitting fluid during pressurization, depending on the pressure applied (Van Opstal et al., 2005).

\subsection{Determination of inactivation and germination of spores}

Each HP treated sample was split in two $300 \mu \mathrm{l}$ portions, of which one was immersed in a water bath at $70{ }^{\circ} \mathrm{C}$ for $30 \mathrm{~min}$ (B. coagulans) or $80^{\circ} \mathrm{C}$ for $10 \mathrm{~min}$ (A. acidoterrestris) to inactivate germinated spores, and the other one was not heated. Both portions were then plated on NA (B. coagulans) and BAT (A. acidoterrestris) agar to count survivors. Pressure-induced inactivation was the difference between the plate count before and after the HP treatment, pressure-induced germination was the difference between the plate count before HP treatment and after HP and heat treatment, expressed in log CFU/ml. The lower detection limit of plating was $10 \mathrm{CFU} / \mathrm{ml}$.

\subsection{Reproducibility of results}

All experiments were conducted in triplicate using a single spore suspension but independent HP treatments, and data are presented as mean values \pm standard deviation. Significant differences were analyzed by Student's $t$-test using a $5 \%$ level of significance $(\mathrm{P}<0.05)$.

\section{Results}

3.1. Germination and inactivation of $\mathrm{B}$. coagulans and A. acidoterrestris spores by $\mathrm{HP}$ treatment at $40{ }^{\circ} \mathrm{C}$ in buffer at neutral and low $\mathrm{pH}$

To study the effect of low $\mathrm{pH}$ on the HP-induced germination and inactivation of $A$. acidoterrestris and $B$. coagulans spores, spore suspensions of $B$. coagulans and $A$. acidoterrestris in citric acid buffer ( $20 \mathrm{mM}, \mathrm{pH} 4.0$ and 5.0 ) or potassium phosphate buffer $(10 \mathrm{mM}$, $\mathrm{pH}$ 7.0) were subjected to HP treatments at 100 to $600 \mathrm{MPa}$ and at $40{ }^{\circ} \mathrm{C}$ for 10 minutes. Since for B. coagulans germination was mostly observed at higher pressures, the pressure range was further extended to $800 \mathrm{MPa}$ for this organism. The temperature of $40{ }^{\circ} \mathrm{C}$ was chosen for this experiment to stimulate germination without causing a thermal pasteurization effect. In those bacterial spores where it has been studied, HP germination is limited or absent at room temperature but rapidly increases at process temperatures of $40{ }^{\circ} \mathrm{C}$ or more (Van Opstal et al., 2004; Wuytack et al., 1998).

The results show that the HP treatments, irrespective of $\mathrm{pH}$ value, caused no significant inactivation of $A$. acidoterrestris spores (Fig. 1B). However, a considerable degree of spore germination was observed, especially in the low pressure range $(100-300 \mathrm{MPa})$ (Fig. 1A). A maximum of about $2.5 \mathrm{log}$ germination occurred at $200 \mathrm{MPa}$ in the pH 7.0 buffer. Germination was lower in the high pressure range and was positively related to $\mathrm{pH}$ at all pressures, except perhaps at $200 \mathrm{MPa}$ where more germination -although not significantly- was observed at pH 4.0 than at $\mathrm{pH}$ 5.0. At $600 \mathrm{MPa}$ there was still between 0.6 and $1 \log$ germination.

B. coagulans showed a markedly different behavior in most aspects. The only point of similarity was the lack of HP inactivation over the entire pressure range and at all $\mathrm{pH}$ values, except perhaps at $800 \mathrm{MPa}$ in $\mathrm{pH} 4.0$ buffer where close to $1 \mathrm{log}$ inactivation was observed (Fig. 1D). However, two additional effects were observed. First, exposure to the low $\mathrm{pH}$ buffer reduced the spore counts of B. coagulans, even without HP or heat treatment, by up to about $0.8 \mathrm{log}$ at $\mathrm{pH}$ 4.0. This was not due to residual vegetative cells in the spore suspension since heat treatment of the $\mathrm{pH} 7.0$ spore suspension did not significantly reduce the counts. Second, at pH 7.0, spore counts increased by about $0.7-0.8 \log$ after HP treatment at all pressures, indicating HP-induced activation of 'superdormant' spores. Remarkably, these superdormant spores were not activated by the heat treatment $\left(70{ }^{\circ} \mathrm{C} / 30 \mathrm{~min}\right.$ ) applied in this work (compare white bar at $0.1 \mathrm{MPa}$ in Fig. 1C and D). It cannot be excluded, of course, that they would have been activated by a higher intensity heat treatment. HP treatment also induced germination of $B$. coagulans spores, but unlike in $A$. acidoterrestris, germination occurred only in the high pressure range ( $500-800 \mathrm{MPa}$ ) and was inversely related to buffer $\mathrm{pH}$ (Fig. 1C). The maximal degree of germination was about $1.8 \mathrm{log}$ and occurred at $700 \mathrm{MPa}$ in the $\mathrm{pH} 4.0$ buffer. As was the case for A. acidoterrestris, germinated spores were not inactivated during the HP treatment.
A

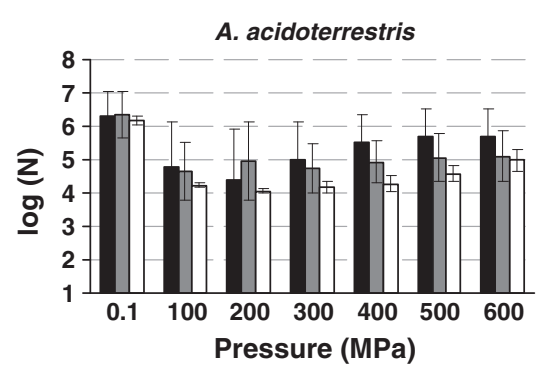

C

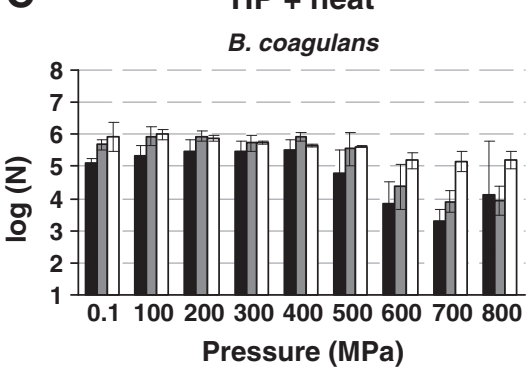

B
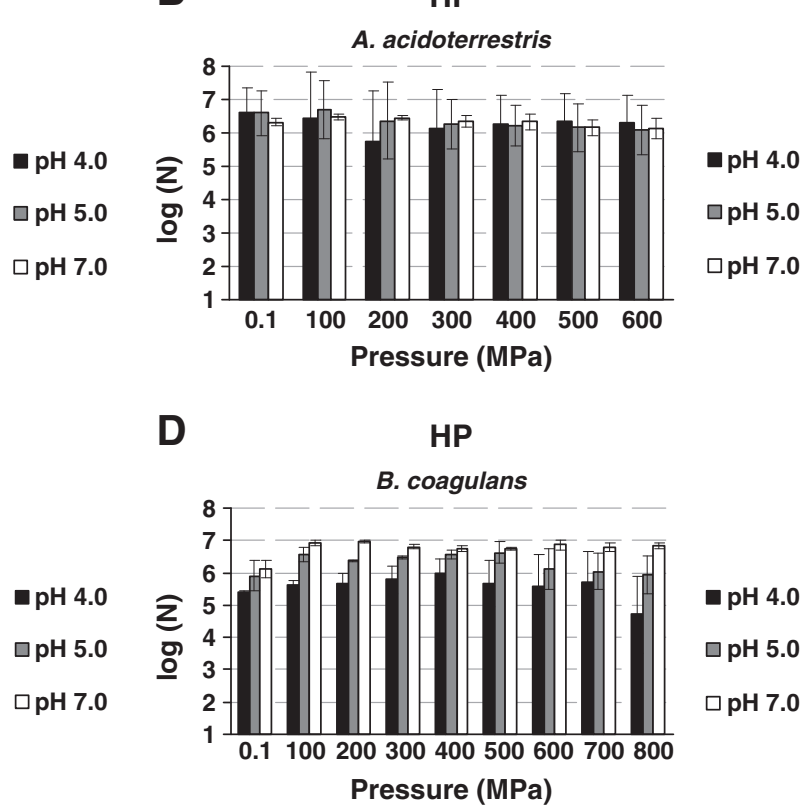

D

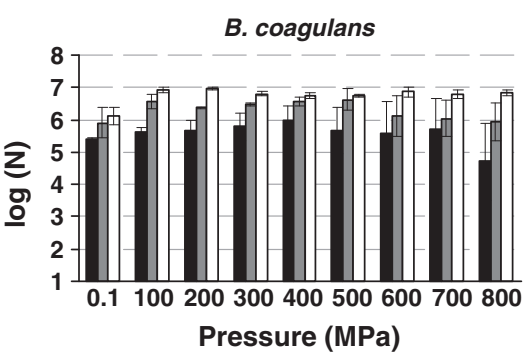

4.0

$\square \mathrm{pH} 5.0$

$\square \mathrm{pH} 7.0$
$-\mathrm{pH} 4.0$

$\square \mathrm{pH} 5.0$

$\square \mathrm{pH} 7.0$

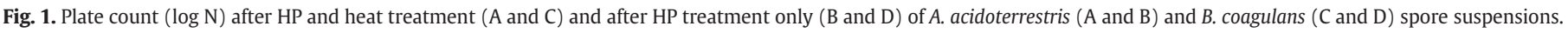

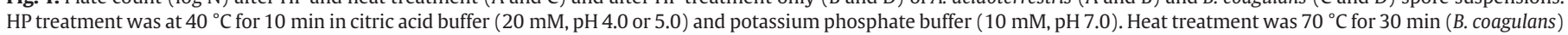
or $80{ }^{\circ} \mathrm{C}$ for $10 \mathrm{~min}$ (A. acidoterrestris). 
3.2. Germination and inactivation of B. coagulans and A. acidoterrestris spores by $\mathrm{HP}$ treatments at $40^{\circ} \mathrm{C}$ in tomato sauce

The above findings with spore suspensions in buffer were validated in a real acidic food by conducting a similar experiment in tomato sauce at pH 4.2 and 5.0. Additionally, HP treatments were not only conducted at $40{ }^{\circ} \mathrm{C}$ but also at 25 and $60{ }^{\circ} \mathrm{C}$ to assess the effect of process temperature on spore germination and inactivation. The results for $A$. acidoterrestris and B. coagulans are shown respectively in Figs. 2 and 3.

For the HP treatment at $40{ }^{\circ} \mathrm{C}$, several effects observed in buffer were confirmed in tomato sauce, but there were also differences, particularly for A. acidoterrestris. Like in buffer, HP treatment alone did not inactivate $A$. acidoterrestris spores in tomato sauce at pH 5.0. However, unlike in buffer at $\mathrm{pH} 4.0$, there was from 1 to $1.5 \log$ inactivation in tomato sauce at $\mathrm{pH} 4.2$ (Fig. 2B and D). Overall, there was more germination of $A$. acidoterrestris spores in tomato sauce than in buffer, with little difference at low and high pressure. Remarkably, there is a trend for germination to be more pronounced at $\mathrm{pH} 4.2$ than at $\mathrm{pH} 5.0$ (however only significant at $5 \%$ level for $200 \mathrm{MPa}$ treatment), which is opposite from what was seen in buffer (Fig. 2A and C). For B. coagulans, observations for the HP treatment at $40^{\circ} \mathrm{C}$ in tomato juice concurred with those in buffer: no inactivation -even some activation- upon pressure treatment alone (Fig. 3B and D), and germination only at $600-800 \mathrm{MPa}$ and more pronounced at the lower $\mathrm{pH}$ value (Fig. $3 \mathrm{~A}$ and $\mathrm{C}$ ).

3.3. Effect of HP process temperature on germination and inactivation of B. coagulans and A. acidoterrestris in tomato sauce

Comparison of the results of HP treatments in tomato sauce at $40{ }^{\circ} \mathrm{C}$ with those at 25 and $60{ }^{\circ} \mathrm{C}$ indicate a strong temperature effect on spore germination and inactivation for both organisms. Since $60^{\circ} \mathrm{C}$ is well below the temperature range where thermal inactivation of spores occurs, we assume that any spore inactivation caused by HP treatment at this temperature is due to spore germination followed by heat inactivation of the germinated spores. In A. acidoterrestris, higher process temperatures did not ( $\mathrm{pH} 4.2$ ) or only moderately ( $\mathrm{pH} 5.0$ ) stimulate germination in the low pressure region, but strongly stimulated germination in the high pressure region. At all temperatures and pressures, germination of $A$. acidoterrestris was higher at $\mathrm{pH}$ 4.2 than at pH 5.0 (Fig. $2 \mathrm{~A}$ and $\mathrm{C}$ ). Inactivation of $A$. acidoterrestris by HP treatment depended on the process temperature but not on the pressure level applied. There was little or no inactivation at $25^{\circ} \mathrm{C}, 1-$
$1.5 \log$ at $40{ }^{\circ} \mathrm{C}$, and $2.5-3.5 \log$ at $60{ }^{\circ} \mathrm{C}$ (Fig. 2B and D). However, even at $60^{\circ} \mathrm{C}$ not all germinated spores were inactivated in the HP process. Finally, spore inactivation of $A$. acidoterrestris was always higher at $\mathrm{pH} 4.2$ than at $\mathrm{pH} 5.0$ with few exceptions, probably as a direct consequence of the higher germination at this low $\mathrm{pH}$.

Similar effects of process temperature were seen for B. coagulans spores. An increase in process temperature strongly stimulated spore germination at high pressures (600-800 MPa), but germination in the low pressure range -which was already absent at $40{ }^{\circ} \mathrm{C}$ - was also not induced even at $60^{\circ} \mathrm{C}$ (Fig. $3 \mathrm{~A}$ and $\mathrm{C}$ ). A process temperature of $60^{\circ} \mathrm{C}$ also resulted in spore inactivation under HP, although, as was the case for $A$. acidoterrestris, not all germinated spores were inactivated (Fig. 3B and D). Finally, a remarkable observation for $B$. coagulans is that the spore activation induced at $40{ }^{\circ} \mathrm{C}$ (even at $0.1 \mathrm{MPa}$ ) is suppressed at $60^{\circ} \mathrm{C}$.

\section{Discussion}

In this work we have studied germination and inactivation of spores from the thermophilic and aciduric B. coagulans and A. acidoterrestris by $\mathrm{HP}$ at moderate temperature in low pH buffer and in tomato sauce. A number of HP studies on these spores have been done previously, but this is the first comprehensive study involving a large number of pressure and temperature combinations in the HP pasteurization domain $\left(\mathrm{T} \leq 60{ }^{\circ} \mathrm{C}\right)$ and addressing not only spore inactivation but also spore germination.

In a first experiment, spore inactivation and germination at different pressures from 100 to 600 or $800 \mathrm{MPa}$ was analyzed in buffers at $\mathrm{pH} 4.0$, 5.0 and 7.0 for comparison (Fig. 1). A process temperature of $40{ }^{\circ} \mathrm{C}$ was chosen for this experiment because bacterial spores often show little or no germination at or below room temperature (Oh and Moon, 2003; Van Opstal et al., 2004; Wuytack et al., 1998). A general conclusion from this experiment for both bacteria is that HP treatment at $40{ }^{\circ} \mathrm{C}$ fails to cause any significant inactivation of the spores, except perhaps for $B$. coagulans at the most extreme condition ( $\mathrm{pH} 4.0,800 \mathrm{MPa}$ ). However, the application of an additional heat treatment after the HP treatment but prior to plating, revealed a considerable degree of spore germination that was dependent on the conditions and that showed a strikingly different pattern for both organisms. A. acidoterrestris spores germinated at all pressures but most extensively at low pressures (100$300 \mathrm{MPa}$ ), whereas $B$. coagulans germinated only at high pressures (500-800 MPa). Furthermore, both bacteria also showed an opposite $\mathrm{pH}$ dependence of spore germination in buffer, with $A$. acidoterrestris germination being somewhat reduced, and $B$. coagulans germination
A
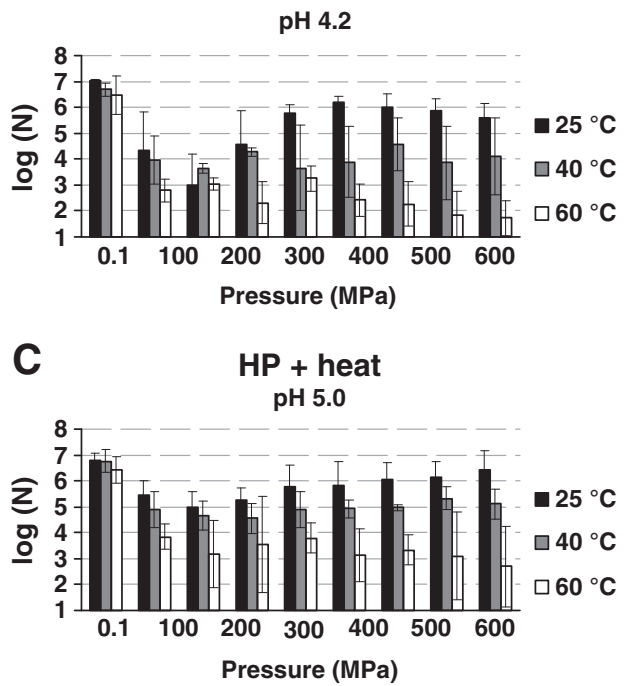

B
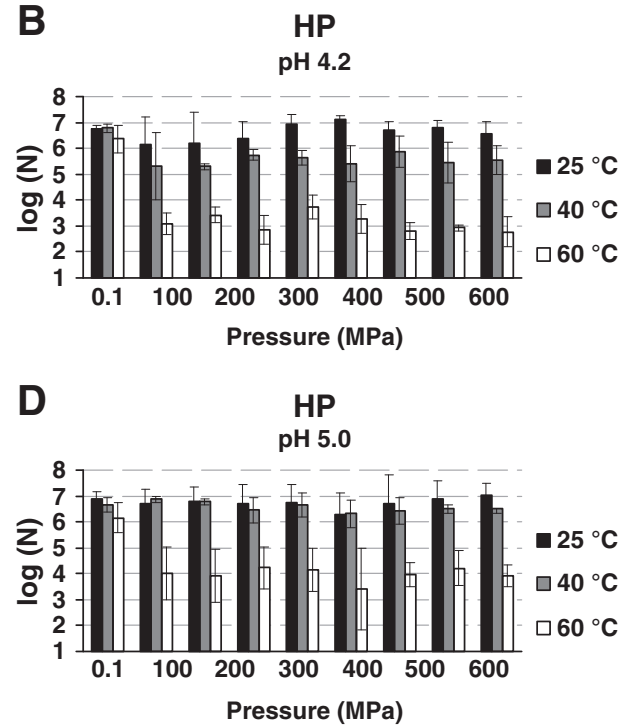

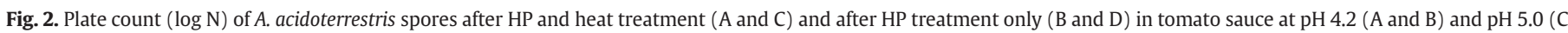
and D). HP process temperatures were 25,40 and $60{ }^{\circ} \mathrm{C}$ for $10 \mathrm{~min}$. Heat treatment was $80{ }^{\circ} \mathrm{C}$ for $10 \mathrm{~min}$. 
A

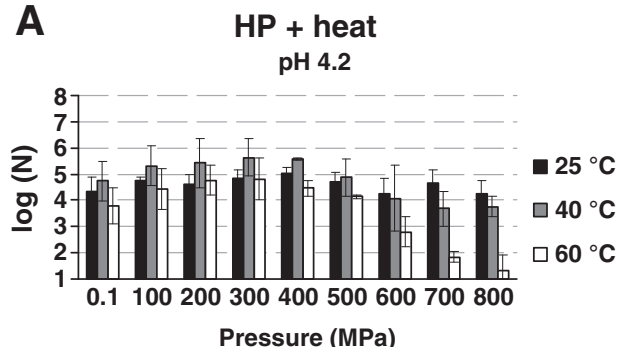

C

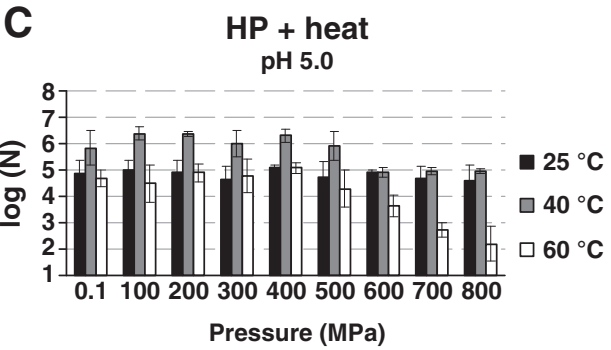

B

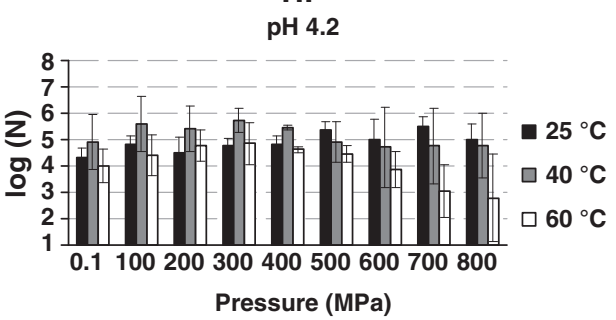

D

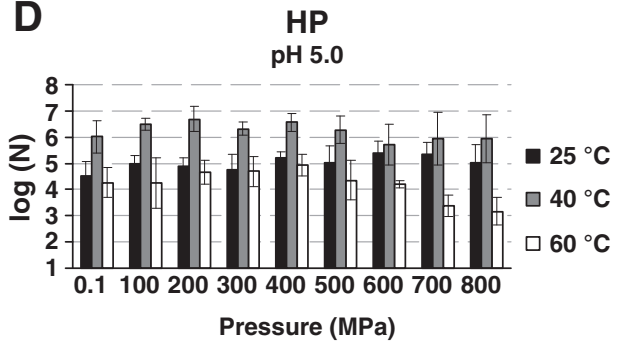

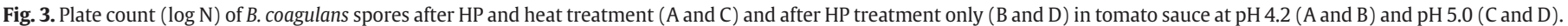
$\mathrm{HP}$ process temperatures were 25,40 and $60{ }^{\circ} \mathrm{C}$ for $10 \mathrm{~min}$. Heat treatment was $70^{\circ} \mathrm{C}$ for $30 \mathrm{~min}$.

being stimulated at low $\mathrm{pH}$. These observations may indicate the existence of physiologically different germination pathways in these bacteria under the conditions of this experiment. The existence of a distinct low and high pressure germination pathway has been demonstrated in B. subtilis previously (Wuytack et al., 1998). A remarkable difference with $B$. subtilis, on the other hand, is the fact that germination can take place at low $\mathrm{pH}$, since HP germination of B. subtilis spores is completely inhibited at $\mathrm{pH}<5.0$ (Wuytack and Michiels, 2001). This may be related to the acidophilic or acidotolerant nature of both $A$. acidoterrestris and B. coagulans, which can grow down to about pH 2.5 (Yamazaki et al., 1996) and 4.0 (Mallidis et al., 1990) respectively. A few additional comments can be made about the behavior of $B$. coagulans spores, based on the data in Fig. 1. First, HP treatment at all pressures causes a slight but consistent increase in spore count at pH 5.0 and 7.0 (e.g. $0.8 \log$ at $100 \mathrm{MPa}$ in pH 7.0 buffer). This may indicate the existence of a small fraction of so-called superdormant spores which are activated by HP treatment. Second, resuspension of $B$. coagulans spores in low pH buffer slightly decreases the spore count (about $0.8 \mathrm{log}$ ). Since the spore suspensions contain little or no vegetative cells, and since $B$. coagulans is acidotolerant, this reduction is unlikely to represent cell death, and the most likely explanation is that an extra fraction of spores is induced to become superdormant at low $\mathrm{pH}$. However, this was not further studied in this work.

In a second experiment, spore germination and inactivation was examined in tomato sauce at $\mathrm{pH} 4.2$ and 5.0 at $40{ }^{\circ} \mathrm{C}$ but also at 25 and $60{ }^{\circ} \mathrm{C}$. At $40{ }^{\circ} \mathrm{C}$, a similar overall pattern was observed as in buffer for both bacteria, except that for $A$. acidoterrestris the effect of $\mathrm{pH}$ on germination was reversed since more germination was detected at $\mathrm{pH}$ 4.2 than at $\mathrm{pH} 5.0$ in tomato sauce. In addition, germination levels were higher for both bacteria in tomato sauce than in buffer. This may be related to a cooperative effect between HP and physiological germinants present in the tomato sauce. A similar effect has been observed before upon HP treatment of B. cereus spores in milk (Van Opstal et al., 2004).

The HP treatments at different temperatures revealed a remarkable difference between germination at low (100-300 MPa) and high (500 $800 \mathrm{MPa}$ ) pressure. High pressure germination, which occurred in both bacteria, showed a strong positive temperature dependence, whereas low pressure germination, which occurred only in A. acidoterrestris was little ( $\mathrm{pH}$ 5.0) or not ( $\mathrm{pH} 4.2$ ) affected by temperature. This is a further indication that the high and low pressure germination proceeds via distinct mechanisms. Spore inactivation was absent or limited when the HP treatment was conducted at 25 or $40{ }^{\circ} \mathrm{C}$ for both bacteria, even under conditions which induced germination. However, at $60^{\circ} \mathrm{C}$, spore inactivation was observed under all the conditions which induced spore germination, and the degree of inactivation was almost equal to the degree of germination, indicating that spore inactivation takes place by pressure-induced germination followed by heat inactivation of the germinated spores. Similar observations have been made for spores of non-acidiphilic bacteria at neutral pH (Sale et al., 1970; Van Opstal et al., 2004). However, spores from neutrophilic bacteria do not germinate under $\mathrm{HP}$ at low $\mathrm{pH}$, and consequently cannot be inactivated by $\mathrm{HP}$ treatment at $60{ }^{\circ} \mathrm{C}$ in acidic foods (Wuytack and Michiels, 2001). Our work shows for the first time that HP induces germination of spores from acidophilic or acidotolerant bacteria at low $\mathrm{pH}$.

The lack of germination in B. coagulans at low pressure, even at $60^{\circ} \mathrm{C}$, may indicate that the low pressure pathway does not exist in this organism. Studies in B. subtilis have shown that low pressure germination proceeds through activation of the nutrient receptors, whereas high pressure germination bypasses these receptors (Wuytack et al., 2000). Thus, it could be that the germinant receptors in $B$. coagulans are not susceptible to HP activation.

The results of this work can be useful to optimize HP pasteurization processes for acidic foods in order to prevent spoilage by thermoacidophilic sporeformers. In principle, two approaches are possible. The first is a two-step approach consisting of a mild 'cold' HP process to induce spore germination followed by the inactivation of the germinated spores, e.g. by a mild heat treatment. The advantage of such a process compared to a purely thermal process is that it causes a much lower thermal burden on the product, since HP germinated spores of $A$. acidoterrestris and B. coagulans can be inactivated at $70-80^{\circ} \mathrm{C}$ (as shown in this work), while inactivation of intact spores requires processing at $90-110^{\circ} \mathrm{C}$ (Ceviz et al., 2009; Palop et al., 1999;). Our results indicate that the two-step approach is only possible for $A$. acidoterrestris, since $B$. coagulans spores can not be germinated by mild cold HP treatment (Fig. 3A and C). For A. acidoterrestris in tomato sauce of $\mathrm{pH} 4.2$, a 4 log reduction can be achieved by treatment at $200 \mathrm{MPa}$ $\left(25^{\circ} \mathrm{C}\right.$ ) for $10 \mathrm{~min}$, followed by heat treatment at $80^{\circ} \mathrm{C}$ (Fig. 2A). Since germination of $A$. acidoterrestris was stimulated by lowering the $\mathrm{pH}$ of the tomato sauce, it is possible that even higher levels of germination, and thus also inactivation, can be achieved with a similar two-step process in more acidic products like apple juice.

The second approach to inactivate $A$. acidoterrestris and B. coagulans spores is a single-step HP process at elevated temperature. For 
A. acidoterrestris, $\mathrm{HP}$ treatment for $10 \mathrm{~min}$ at $60{ }^{\circ} \mathrm{C}$ caused 2.5 - $3.5 \mathrm{log}$

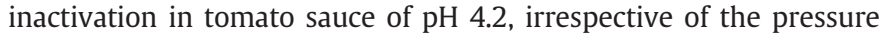
used (Fig. 2B). However, it is likely that higher levels of inactivation can be achieved by further increasing the process temperature, as was demonstrated by Lee et al. (2002) for A. acidoterrestris spores in apple juice. For $B$. coagulans, HP processing at $60{ }^{\circ} \mathrm{C}$ required high pressures to induce germination and achieve inactivation. In the $\mathrm{pH}$ 4.2 tomato sauce, a $10 \mathrm{~min}$ treatment at $700 \mathrm{MPa}\left(60^{\circ} \mathrm{C}\right)$ resulted in a $2 \log$ inactivation. For comparison, Roberts and Hoover (1996) reported 2 and $4.5 \log$ inactivation of $B$. coagulans in Mcllvaine buffer ( $\mathrm{pH} 4.0$ ) upon treatment at $400 \mathrm{MPa}$ for $15 \mathrm{~min}$ at 45 and $70{ }^{\circ} \mathrm{C}$ respectively, indicating that the spores of some strains of $B$. coagulans can be germinated at lower pressures.

In conclusion, we demonstrated that HP treatment can induce germination of $A$. acidoterrestris and $B$. coagulans spores in acidic conditions. This phenomenon is probably linked to the acidophilic character of these bacteria, since germination of spores from the neutrophilic B. subtilis is inhibited at low pH. Further, HP treatments conducted at moderately elevated temperature (e.g. $60{ }^{\circ} \mathrm{C}$ ) or followed by a moderate heat treatment can kill these acidothermophilic spores, and thus offer perspectives to reduce spoilage problems with acidic products caused by these bacteria.

\section{Acknowledgements}

This work was supported by the K.U.Leuven Research Fund (METH/07/03)

\section{References}

Benito, A., Ventoura, G., Casadei, M., Robinson, T., Mackey, B., 1999. Variation in resistance of natural isolates of Escherichia coli 0157 to high hydrostatic pressure, mild heat, and other stresses. Appl. Environ. Microbiol. 65, 1564-1569.

Ceviz, G., Tulek, Y., Con, A.H., 2009. Thermal resistance of Alicyclobacillus acidoterrestris spores indifferent heating media. Int. J. Food Sci. Technol. 44, 1770-1777.

Clouston, J.G., Wills, P.A., 1969. Initiation of germination and inactivation of Bacillus pumillus spores by high hydrostatic pressure. J. Bacteriol. 97, 684-690.

Evancho, G.M., Walls, I., 2001. Aciduric flat sour sporeformers, In: Downes, F.P., Ito, K. (Eds.), Compendium of methods for the microbiological examination of foods, fourth edition. American Public Health Association, Washington, DC, pp. 239-244.

Gould, G.W., Sale, A.J.H., 1970. Initiation of germination of bacterial spores by hydrostatic pressure. J. Gen. Microbiol. 60, 335-346.

Hauben, K.J.A., Bartlett, D.H., Soontjes, C.C.F., Cornelis, K., Wuytack, E.Y., Michiels, C.W., 1997. Escherichia coli mutants resistant to inactivation by high hydrostatic pressure. Appl. Environ. Microbiol. 63, 945-950.
Islam, M.S., Inoue, A., Igura, N., Shimoda, M., Hayakawa, I., 2006. Inactivation of Bacillus spores by the combination of moderate heat and low hydrostatic pressure in ketchup and potage. Int. J. Food Microbiol. 107, 124-130.

Lee, S.-Y., Dougherty, R.H., Kang, D.-H., 2002. Inhibitory effects of high pressure and heat on Alicyclobacillus acidoterrestris spores in apple juice. Appl. Environ. Microbiol. 68, 4158-4161.

Lee, S.-Y., Chung, H.-Y., Kang, D.-H., 2006. Combined treatment of high pressure and heat on killing spores of Alicyclobacillus acidoterrestris in apple juice concentrate. J. Food Prot. 69, 1056-1060.

Mallidis, C.G., Frantzeskakis, P., Balatsouras, G., Katsabotxakis, C., 1990. Thermal treatment of aseptically processed tomato paste. Int. J. Food Sci. Technol. 25 442-448.

Nakayama, A., Yano, Y., Kobayashi, S., Ishikawa, M., Sakai, K., 1996. Comparison of pressure resistances of spores of six Bacillus strains with their heat resistances. Appl. Environ. Microbiol. 62, 3897-3900.

Oh, S., Moon, M.J., 2003. Inactivation of Bacillus cereus spores by high hydrostatic pressure at different temperatures. J. Food Prot. 66, 599-603.

Palop, A., Raso, J., Pagán, R., Condón, S., Sala, F.J., 1999. Influence of pH on heat resistance of spores of Bacillus coagulans in buffer and homogenized foods. Int. J. Food Microbiol. 46, 243-249.

Roberts, C.M., Hoover, D.G., 1996. Sensitivity of Bacillus coagulans spores to combinations of high hydrostatic pressure, heat, acidity and nisin. J. Appl. Bacteriol. 81, 363-368.

Sale, A.J.H., Gould, G.W., Hamilton, W.A., 1970. Inactivation of bacterial spores by hydrostatic pressure. J. Gen. Microbiol. 60, 323-334.

Silva, F.V.M., Gibbs, P., 2004. Target selection in designing pasteurisation processes for shelf-stable high-acid fruit products. Crit. Rev. Food Sci. Nutr. 44, 353-360.

Sinigaglia, M., Corbo, M.R., Altieri, C., Campaniello, D., D'amato, D., Bevilacqua, A., 2003 Combined effects of temperature, water activity, and $\mathrm{pH}$ on Alicyclobacillus acidoterrestris spores. J. Food Prot. 66, 2216-2221.

Smelt, J.P.P.M., 2002. Recent advances in the microbiology of high pressure processing Trends Food Sci. Technol. 9, 152-158.

Splittstoesser, D.F., Churey, J.J., Lee, C.Y., 1994. Growth characteristics of aciduric sporeforming bacilli isolated from fruit juices. J. Food Prot. 57, 1080-1083.

Van Opstal, I., Bagamboula, C., Vanmuysen, S., Wuytack, E., Michiels, C.W., 2004 Inactivation of Bacillus cereus spores in milk by mild pressure and heat treatments. Int. J. Food Microbiol. 92, 227-234.

Van Opstal, I., Vanmuysen, S.C.M., Wuytack, E.Y., Masschalck, B., Michiels, C.W., 2005 Inactivation of Escherichia coli by high hydrostatic pressure at different temperatures in buffer and carrot juice. Int. J. Food Microbiol. 98, 179-191.

Wang, B.-S., Li, B.-L., Zeng, Q.-X., Huang, J., Ruan, Z., Zhu, Z.-W., Li, L., 2009. Inactivation kinetics and reduction of Bacillus coagulans spore by the combination of high pressure and moderate heat. J. Food Process Eng 32, 692-708.

Wuytack, E.Y., Boven, S., Michiels, C.W., 1998. Comparative study of pressure-induced germination of Bacillus subtilis spores at low and high pressures. Appl. Environ. Microbiol. 64, 3220-3224.

Wuytack, E.Y., Soons, J., Poschet, F., Michiels, C.W., 2000. Comparative study of pressureand nutrient-induced germination of Bacillus subtilis spores. Appl. Environ. Microbiol. 66, 257-261.

Wuytack, E.Y., Michiels, C.W., 2001. A study on the effects of high pressure and heat on Bacillus subtilis spores at low pH. Int. J. Food Microbiol. 64, 333-341.

Yamazaki, K., Teduka, H., Shinano, H., 1996. Isolation and identification of Alicyclobacillus acidoterrestris from acidic beverages. Biosci. Biotechnol. Biochem. 60, 543-545. 